\title{
Using chromium isotopes to study chromium cycling in the Eastern Tropical South Pacific oxygen deficient zones
}

\author{
TIANYI HUANG AND EDWARD ALLEN BOYLE
}

Massachusetts Institute of Technology

Presenting Author: tyhuang@mit.edu

The Eastern Tropical South Pacific (ETSP) is one of the largest oxygen deficient zones (ODZs) in the global ocean, thus is also a suitable region to study the redox processes of chromium $(\mathrm{Cr})$. Filtered seawater samples of the ETSP were collected from GEOTRACES Eastern Tropical Pacific Transect (GP16). Frozen samples from two stations in the ODZ $\left(79.2^{\circ} \mathrm{W}\right.$, $\left.12^{\circ} \mathrm{S} ; 94^{\circ} \mathrm{W}, 12^{\circ} \mathrm{S}\right)$ were analyzed for $\mathrm{Cr}(\mathrm{III})$ isotopes. The $\mathrm{Cr}(\mathrm{III})$ concentration ranges from 0.79 to $1.85 \mathrm{nmol} / \mathrm{kg}$, accounting for $24 \%$ to $71 \%$ of the total dissolved $\mathrm{Cr}$ at the same depth. The $\mathrm{Cr}(\mathrm{III})$ has isotopic compositions ranging from $-0.26 \%$ to $0.98 \%$. Both the highest $\mathrm{Cr}$ (III) concentration and heaviest $\mathrm{Cr}$ (III) occur in the upper core of the ODZ $\left(\sigma_{\theta} \sim 26.4\right.$ $\mathrm{kg} / \mathrm{m}^{3}$ ). This density layer is also where the largest $\mathrm{Cr}$ depletion was observed when comparing ODZ stations to an oxic station $\left(145^{\circ} \mathrm{W}, 10.9^{\circ} \mathrm{S}\right)$ in the western gyre. And the calculated scavenged $\mathrm{Cr}$ is isotopically lighter than the total dissolved $\mathrm{Cr}$, with an average $\delta^{53} \mathrm{Cr}$ difference between the scavenged $\mathrm{Cr}$ and $\mathrm{Cr}(\mathrm{III})$ being $-0.03 \%$ o $(\mathrm{n}=5)$. This implies that the isotopic fractionation of scavenging is small. We also found that the isotopic fractionation of $\mathrm{Cr}$ reduction in the ETSP is similar to that in the ETNP $(-1.3 \pm 0.1 \%)$, as is reported in a recent study ${ }^{[1]}$. Another similarity between the two ODZs is the cooccurrence of $\mathrm{Cr}(\mathrm{III})$ maximum and other reduced species, such as $\mathrm{Fe}(\mathrm{II})$, iodide and nitrite ${ }^{[2]}$. This indicates that for both ETSP and ETNP, Cr reduction might be coupled with these redox species or microbial denitrification.

[1] Huang, T., Moos, S. B., \& Boyle, E. A. (2021). Trivalent chromium isotopes in the eastern tropical North Pacific oxygendeficient zone. Proceedings of the National Academy of Sciences, 118(8) e1918605118.

[2] Cutter, G. A., Moffett, J. W., Nielsdóttir, M. C., \& Sanial, V. (2018). Multiple oxidation state trace elements in suboxic waters off Peru: In situ redox processes and advective/diffusive horizontal transport. Marine Chemistry, 201, 77-89. 